\title{
Adenosine Receptor Antagonists to Combat Cancer and to Boost Anti-Cancer Chemotherapy and Immunotherapy
}

\author{
Rafael Franco ${ }^{1,2, *(\mathbb{D})}$, Rafael Rivas-Santisteban ${ }^{1,2}\left(\mathbb{D}\right.$, Gemma Navarro ${ }^{1,3}(\mathbb{D})$ and Irene Reyes-Resina ${ }^{1,2,+}(\mathbb{D})$ \\ 1 CiberNed, Network Research Center, Neurodegenerative Diseases, Spanish National Health Institute Carlos \\ III, 28034 Madrid, Spain; rrivasbioq@gmail.com (R.R.-S.); g.navarro@ub.edu (G.N.); \\ ire-reyes@hotmail.com (I.R.-R.) \\ 2 Department of Biochemistry and Molecular Biomedicine, University of Barcelona, 08028 Barcelona, Spain \\ 3 Department of Biochemistry and Physiology, Faculty of Pharmacy and Food Science, University of Barcelona, \\ 08028 Barcelona, Spain \\ * Correspondence: rfranco@ub.edu or rfranco123@gmail.com \\ † Current Address: RG Neuroplasticity, Leibniz Institute for Neurobiology, 39118 Magdeburg, Germany.
}

Citation: Franco, R.

Rivas-Santisteban, R.; Navarro, G.; Reyes-Resina, I. Adenosine Receptor Antagonists to Combat Cancer and to Boost Anti-Cancer Chemotherapy and Immunotherapy. Cells 2021, 10, 2831. https://doi.org/10.3390/ cells10112831

Academic Editor: Anthony Ashton

Received: 9 September 2021

Accepted: 16 October 2021

Published: 21 October 2021

Publisher's Note: MDPI stays neutral with regard to jurisdictional claims in published maps and institutional affiliations.

\begin{abstract}
Extracellular adenosine accumulates in the environment of numerous tumors. For years, this fact has fueled preclinical research to determine whether adenosine receptors (ARs) could be the target to fight cancer. The four $A R s$ discovered so far, $A_{1}, A_{2 A}, A_{2 B}$ and $A_{3}$, belong to the class A family of $G$ protein-coupled receptors (GPCRs) and all four have been involved in one way or another in regulating tumor progression. Prompted by the successful anti-cancer immunotherapy, the focus was placed on the ARs more involved in regulation of immune cell differentiation and activation and that are able to establish molecular and functional interactions. This review focuses on the potential of $\mathrm{A}_{2 \mathrm{~A}}$ and $\mathrm{A}_{2 \mathrm{~B}}$ receptor antagonists in cancer control and in boosting anti-cancer chemotherapy and immunotherapy. The article also overviews the ongoing clinical trials in which $\mathrm{A}_{2 \mathrm{~A}} \mathrm{R}$ and $\mathrm{A}_{2 \mathrm{~B}} \mathrm{R}$ ligands are being tested in anti-cancer therapy.
\end{abstract}

Keywords: $\mathrm{A}_{2 \mathrm{~A}}$ adenosine receptor; $\mathrm{A}_{2 \mathrm{~B}}$ adenosine receptor; clinical trial; carcinoma; metastases; chemoradiation; glioma; neuroblastoma

\section{Introduction}

Adenosine (Ado) was considered a molecule that protects against cancer. One example is muscle, which is always involved in ATP/Ado/ATP cycles. In fact, striated muscles have little risk of metastasis implantation. Twenty years ago, it was discovered that oral administration of a muscle cell conditioned medium inhibited tumor growth in mice [1] Adenosine was responsible for the effect and the action was mainly mediated by the $\mathrm{A}_{3}$ receptor, which is one of the four identified proteins that sense extracellular adenosine: $A_{1}, A_{2 A}, A_{2 B}$ and $A_{3}$ [2] (see below for a general description of adenosine receptors). Interestingly, it was postulated that, in addition to adenosine, muscle cells produced other compounds ("stable, nondegradable") that behave as agonists of the $A_{3}$ receptor $\left(A_{3} R\right)$ [1]

It has been assumed that extracellular adenosine plays a key role in minimizing the occurrence of tumors in muscle (heart included). The compound has been defined as "multi-signaling guardian angel in human diseases" [3]. However Ado accumulates in the environment of several tumor types and Jozef Spychala wrote in 2000 an article entitled: "Tumor-promoting functions of adenosine" [4]. Is Ado friend or foe? As is often the case, the answer is: it depends. From a therapeutic point of view, it is evident that in cancers in which Ado acts as a foe, the use of antagonists of ARs may help, and this is the basis of trials to assess the efficacy of AR antagonists as boosters of chemotherapeutic agents, with potential also in radiotherapy. Due to the fact that ARs mediate the regulation of the immune system by Ado, ligands of those receptors may act as boosters in the relatively recent and highly efficacious monoclonal antibody-based immunotherapeutic anti-cancer approach. Here, 
we present an overview of the possibility of targeting adenosine receptors (ARs) in the fight against cancer. Due to the fact that the aim of the article is not reviewing all possibilities of all ARs on all cancers, we will focus on the potential of those that have, as of today, more chances to be targeted if Ado-related medication arrives to the bedside of the patient with cancer, namely the $A_{2 A}$ receptor $\left(A_{2 A} R\right)$ and the $A_{2 B}$ receptor $\left(A_{2 B} R\right)$. Seemingly, there is not any clinical trial registered in ClinicalTrials.gov (CTg) to target the $A_{1} R$ in cancer. As for the $A_{3} R$, there are two clinical trials registered to test agonist in hepatic carcinoma; the last study was posted in May 2014 (CTg Identifier: NCT02128958) and results, recently reported, show a good safety profile and modest efficacy [5]. For readers interested in anti-cancer approaches taking adenosine as reference, but from a metabolic perspective, the review by Boison and Yegutkin (2019) is strongly recommended [6]. Authors point out "the need for a more careful evaluation of the entire purinome in emerging cancer therapies" and list the clinical trials on the efficacy of anti-cancer therapies of molecules altering the metabolic balance of adenine nucleotides and nucleosides.

\section{Adenosine and Adenosine Receptors}

Ado, the adenine purine nucleoside, is an autacoid, which is defined by Merriam Webster dictionary as: "a physiologically active substance (such as serotonin, bradykinin, or angiotensin) that is produced by the body and typically has a localized effect of brief duration". Ado is found in every cell in the human body. Ado is metabolically related to adenosine triphosphate (ATP) and is therefore present in almost any living cell on the Earth's surface. Apart from its relevance for energy metabolism within the cell, it can be released into the extracellular environment where it becomes an important modulator that acts through specific receptors located on the cell surface. Purinergic P1 receptors, more commonly known as Ado receptors (ARs), belong to class A rhodopsin-like G protein-coupled receptors (GPCRs) and four have been discovered so far. Before the cloning technique was available, pharmacological tools allowed the discovery of 3 receptors that were named as $A_{1}, A_{2}$ and $\mathrm{A}_{3}$; one more receptor was identified by cloning its cDNA, and the nomenclature that holds today is: $A_{1}, A_{2 A}, A_{2 B}$ and $A_{3}$. Whereas $A_{1}$ and $A_{3}$ receptors couple to $G_{i / o}$, whose engagement leads to reduction in the activity of the adenylyl cyclase, the canonical proteins that couple to $A_{2 A}$ or to $A_{2 B}$ receptors are of the $G_{S}$ family, whose engagement leads to an increase in the activity of the adenylyl cyclase [2]. A comprehensive review on adenosine receptors and cancer was written in 2009 by Fishman et al. [7]. A more recent review provides hints on how Ado receptors have become targets to combat cancer [8].

\section{Therapeutic Drugs Acting on ARs}

Despite the huge amount of research on ARs and the potential of ligands acting on them, specially of antagonists, few AR-related drugs have been approved for human use. The first was Ado itself, which can be used in the emergency room to convert lifethreatening paroxysmal tachycardia into sinus rhythm. Indeed, the physiological actions of adenosine on the heart were already discovered in the nineteen-twenties by Drury and Szent-Györgyi [9]. A couple of decades later, the laboratory of Berne provided the molecular and clinical basis for the use of Ado in paroxysmal tachycardia [10,11]. Despite the usefulness of Ado in such extreme condition, AR agonists do have, generally speaking, unwanted side effects.

Unlike agonists, AR antagonists are generally safe, and this property has helped in the approval of AR antagonists in two phases. First, the non-selective antagonists, that were already being taken as part of coffee/tea/cola beverages, were approved. Several years later, a selective $A_{2 A} R$ antagonist was approved as the first drug in its class, opening the door for further approval of AR antagonists in the future. In fact, non-selective AR antagonists, known as methylxanthines due to their chemical structure, were approved several years ago for some conditions such as asthma. The best known methylxanthines are caffeine and theophylline, that have been consumed for centuries in different cultures as components of beverages, such as coffee, tea and mate. Actually, caffeine is the most 
consumed psychoactive substance in the world (present in coffee, tea and cola drinks). Importantly, methylxanthines as the recently approved AR-related drug: istradefylline are safe. Istradefylline is a selective antagonist of the $\mathrm{A}_{2 \mathrm{~A}} \mathrm{R}$ that was first approved in Japan (Nouriast $^{\circledR}$ ) and later in the US (Nourianz ${ }^{\circledR}$ ) as adjuvant in the therapy of Parkinson's disease [12-16]. Regadenoson (Lexiscan ${ }^{\circledR}$ ), an $\mathrm{A}_{2 \mathrm{~A}} \mathrm{R}$ agonist, is not used in therapy but in diagnosis of alterations of myocardial perfusion [17-19]. Unfortunately, Regadenoson has been tested, without success, for making the blood-brain barrier more permeable to drugs that need to enter the brain to attack gliomas and neuroblastomas, some of which are very aggressive and have a poor prognosis $[20,21]$.

Ado, like almost all regulatory molecules that act on cell surface GPCRs, exerts multiple actions based on various parameters. Ado action depends on the tissue, it may even be different in different parts of the tissue. Importantly, the expression of receptors that mediate Ado actions may vary in response to various stimuli or may be under circadian variations. One of the best known examples is the regulation of AR expression in response to caffeine intake [22,23]. Taking the kidney as a model, the expression of the four ARs happens to be heterogeneous when considering the different anatomical regions [24-27]; even in a single renal tubular epithelial cell, the expression may be fairly different in the basolateral and luminal membranes [28,29]. Finally, a given AR may be present in different cell types in different anatomical regions of a given tissue, the most extreme case being the brain, where ARs are heterogeneously distributed with eventual enrichments such as the high expression of the $A_{2 A} R$ in the striatum. On the other hand, $A R$ in tumor cells may be up or down regulated and each AR type may have opposite roles, thus raising doubts on the best way to attack a given cancer. A very detailed review on the expression of ARs in different tumor cells lines and the signaling pathways and effects, among them proliferative versus antiproliferative, following AR activation has been recently provided by Kazemi et al. [30]. In a recent review on breast cancer, it is stated that "among the P1 receptors, the $A_{1}, A_{2 A}$, and $A_{2 B}$ receptors are involved in the proliferation and invasion of breast cancer, while the $A_{3}$ receptor is related to the inhibition of tumor growth" [31]. In this complex scenario, is targeting ARs a therapeutic option in anti-cancer therapy?

At the preclinical level, there have been several investigations aimed at combating cancer using ligands targeting ARs. As many of the approved drugs targeting GPCRs, those ligands are designed and prepared for oral administration. However, it is quite difficult to find a certain cancer that can be cured by targeting ARs. The main role of AR activation is not the suppression or induction of gene expression, and consequently, it is difficult to find a scenario in which tumor growth can be stopped by targeting these receptors. Despite these theoretical limitations, a compound from Palobiofarma, PBF-1129, which is a selective $A_{2 B} R$ antagonist, is in phase 1 clinical trials to be further tested for efficacy in locally advanced or metastatic lung cancer (CTg Identifier: NCT03274479). Another selective $\mathrm{A}_{2 \mathrm{~B}} \mathrm{R}$ antagonist, TT-4 (from Tarus Therapeutics), is also being tested in phase $1 / 2$ in patients with advanced solid tumors (CTg Identifier: NCT04976660).

It should be noted that there is a dual $\mathrm{A}_{2 \mathrm{~A}} / \mathrm{A}_{2 \mathrm{~B}}$ receptor antagonist, etrumadenant (or AB928), which when tested in phase 1 clinical trials showed good safety scores and excellent pharmacokinetics after oral administration [32]. According to the NCT03720678 trial (ClinicalTrials.gov, now in phase 1/1b), AB928 will be tested for efficacy in gastroesophageal and colorectal cancers; there are also expectations that the compound could be an efficacious adjuvant in radiotherapy, chemotherapy and immunotherapy approaches. Actually, the most likely scenario is that AR activation or blockade could serve as adjunctive therapy in chemotherapeutic and immunotherapeutic (even chemoradiation/radiotherapeutic) approaches to combat a wide variety of cancers. The next two sections aim at answering these questions: (i) is AR targeting an effective means to enhance anti-cancer immunotherapy? and (ii) is AR targeting an effective means to enhance anti-cancer chemotherapy?

Due to the approval of $A_{2 A} R$ antagonists in the therapy of Parkinson's disease, the safety of other $A_{2 A} R$ antagonists has been tested, and they turned out to be generally safe. One of them, which was intended to be in line for Parkinson's disease, has entered into 
clinical trials for cancer, even as a monotherapy: NIR178 (PBF-509) in advanced cases of lung cancer (CTg Identifier: NCT02403193; phase 1-2) [33] or TT-10 to treat patients with "advanced" solid tumors (CTg Identifier: NCT04969315). The list of ongoing clinical trials targeting $\mathrm{A}_{2 \mathrm{~A}}$ or $\mathrm{A}_{2 \mathrm{~B}}$ receptors is in Table 1 (source Clinicaltrials.gov; accessed on 7 October 2021).

Table 1. Ongoing clinical trials registered at Clinicaltrials.gov in which $A_{2 A}$ or $A_{2 B}$ receptors are targeted to combat malignancies.

\begin{tabular}{|c|c|c|c|c|c|}
\hline Target * & $\begin{array}{c}+/- \text { Combination } \\
\text { Therapy }\end{array}$ & Company /Institution & Cancer Type & $\begin{array}{l}\text { Clinicaltrials.Gov } \\
\text { Identifier }\end{array}$ & Study Phase \\
\hline $\mathrm{A}_{2 \mathrm{~A}} \mathrm{R}$ & $\begin{array}{l}\text { Inupadenant + EOS-448 } \\
\text { (anti-TIGIT mAB) }\end{array}$ & iTeos Therapeutics & AST & NCT05060432 & 1,2 (NR) \\
\hline $\mathrm{A}_{2 \mathrm{~A}} \mathrm{R}$ & $\begin{array}{l}\text { Ciforadenant }+/- \\
\text { atezolizumab }(\mathrm{mAb} \\
\text { against } \mathrm{PD}-1)\end{array}$ & $\begin{array}{c}\text { Corvus } \\
\text { Pharmaceuticals, Inc. }\end{array}$ & $\begin{array}{c}\text { Prostate (ad- } \\
\text { vanced/incurable) }\end{array}$ & NCT02655822 & $1,1 b(\mathrm{R}, \mathrm{OL})$ \\
\hline $\mathrm{A}_{2 \mathrm{~A}} \mathrm{R}$ & $\begin{array}{l}\text { PBF- } 509+/- \text { antibody } \\
\text { against PD-1 }\end{array}$ & Palobiofarma SL & NSLC (advanced) & NCT02403193 & $1,2(\mathrm{NR}, \mathrm{OL})$ \\
\hline $\mathrm{A}_{2 \mathrm{~A}} \mathrm{R}$ & $\begin{array}{c}\text { Taminadenant }+ \\
\text { Spartalizumab (mAb } \\
\text { against PD-1) + DFF332 } \\
(\text { Hif } 2 \alpha \text { inhibitor })\end{array}$ & $\begin{array}{c}\text { Novartis } \\
\text { Pharmaceuticals }\end{array}$ & Renal (advanced) & NCT04895748 & $1,1 \mathrm{~b}(\mathrm{NR}, \mathrm{OL})$ \\
\hline $\mathrm{A}_{2 \mathrm{~A}} \mathrm{R}$ & $\begin{array}{c}\text { NIR178 + / - } \\
\text { Spartalizumab (mAb } \\
\text { against PD-1 }\end{array}$ & $\begin{array}{c}\text { Novartis } \\
\text { Pharmaceuticals }\end{array}$ & Solid tumor, NHL & NCT03207867 & $2(\mathrm{NR}, \mathrm{OL})$ \\
\hline $\mathrm{A}_{2 \mathrm{~A}} \mathrm{R}$ & PBF -509 & Palobiofarma SL & $\begin{array}{l}\text { NA (safety } \\
\text { assessment) }\end{array}$ & NCT01691924 & $1(\mathrm{R})$ \\
\hline $\mathrm{A}_{2 \mathrm{~A}} \mathrm{R}$ & PBF -509 & $\begin{array}{c}\text { Fundació Institut de } \\
\text { Recerca de l'Hospital } \\
\text { de la Santa Creu i Sant } \\
\text { Pau }\end{array}$ & Cancer (general) & NCT02111330 & $1(\mathrm{R}, \mathrm{DB}, \mathrm{PC})$ \\
\hline $\mathrm{A}_{2 \mathrm{~A}} \mathrm{R}$ & $\begin{array}{c}\text { Ciforadenant }+ \\
\text { daratumumab }(\mathrm{mAb} \\
\text { against CD38) }\end{array}$ & $\begin{array}{c}\text { Corvus } \\
\text { Pharmaceuticals, Inc. }\end{array}$ & Multiple Myeloma & NCT04280328 & $1(\mathrm{OL})$ \\
\hline $\mathrm{A}_{2 \mathrm{~A}} \mathrm{R}$ & TT-10 & Tarus Therapeutics & $\begin{array}{l}\text { Renal, prostate, } \\
\text { NSCLC (AST) }\end{array}$ & NCT04969315 & $1,2(\mathrm{OL})$ \\
\hline $\mathrm{A}_{2 \mathrm{~B}} \mathrm{R}$ & TT-4 & Tarus Therapeutics & $\begin{array}{l}\text { Gastrointestinal, } \\
\text { hepatocellular, } \\
\text { prostate }\end{array}$ & NCT04976660 & $1,2(\mathrm{OL})$ \\
\hline$A_{2 A} R / A_{2 B} R$ & $\begin{array}{c}\text { Arm 1: } \\
\text { AB928/Etrumadenant + } \\
\text { zimberelimab (mAb } \\
\text { against PD-1) + } \\
\text { enzalutamide } \\
\text { Arm 2: } \\
\text { AB928/Etrumadenant + } \\
\text { zimberelimab (mAb } \\
\text { against PD-1) + docetaxel }\end{array}$ & Arcus Biosciences, Inc. & $\begin{array}{c}\text { Prostate (ad- } \\
\text { vanced/incurable) }\end{array}$ & NCT04381832 & $1,2(\mathrm{R}, \mathrm{OL})$ \\
\hline $\mathrm{A}_{2 \mathrm{~A}} \mathrm{R} / \mathrm{A}_{2 \mathrm{~B}} \mathrm{R}$ & $\begin{array}{l}\text { AB928/Etrumadenant } \\
\text { (dual antagonist) }+ \\
\text { zimberelimab (mAb } \\
\text { against PD-1) }\end{array}$ & Arcus Biosciences, Inc. & $\begin{array}{l}\text { Advanced } \\
\text { malignancies }\end{array}$ & NCT03629756 & 1 (NR, OL) \\
\hline
\end{tabular}


Table 1. Cont.

\begin{tabular}{|c|c|c|c|c|c|}
\hline Target * & $\begin{array}{c}+/- \text { Combination } \\
\text { Therapy }\end{array}$ & Company /Institution & Cancer Type & $\begin{array}{l}\text { Clinicaltrials.Gov } \\
\text { Identifier }\end{array}$ & Study Phase \\
\hline $\mathrm{A}_{2 \mathrm{~A}} \mathrm{R} / \mathrm{A}_{2 \mathrm{~B}} \mathrm{R}$ & $\begin{array}{c}\text { AB928/Etrumadenant } \\
\text { (dual antagonist) }+ \\
\text { Cisplatin/Radiation } \\
\text { Therapy + Zimberelimab } \\
\text { (mAb against PD-1) }\end{array}$ & $\begin{array}{l}\text { Jennifer Choe in } \\
\text { collaboration with } \\
\text { Arcus Biosciences Inc }\end{array}$ & Head and neck & NCT04892875 & $1(\mathrm{NR}, \mathrm{OL})$ \\
\hline $\mathrm{A}_{2 \mathrm{~A}} \mathrm{R} / \mathrm{A}_{2 \mathrm{~B}} \mathrm{R}$ & $\begin{array}{c}\text { Arm } 1 . \\
\text { AB928/Etrumadenant } \\
\text { (dual antagonist) }+ \\
\text { zimberelimab (mAb } \\
\text { against PD-1) + standard } \\
\text { chemotherapeutic regime } \\
\text { (mFOLFOX-6 + } \\
\text { bevacizumab) } \\
\text { Arm 2: } \\
\text { AB928/Etrumadenant } \\
\text { zimberelimab (mAb } \\
\text { against PD-1) + AB680 } \\
\text { (CD73 inhibitor) }\end{array}$ & Arcus Biosciences Inc. & Colon (metastatic) & NCT04660812 & $1,2(\mathrm{R}, \mathrm{OL})$ \\
\hline $\mathrm{A}_{2 \mathrm{~A}} \mathrm{R} / \mathrm{A}_{2 \mathrm{~B}} \mathrm{R}$ & $\begin{array}{c}\text { AB928/Etrumadenant } \\
\text { (dual antagonist) }+ \\
\text { Carboplatin and } \\
\text { Pemetrexed }+/- \\
\text { Zimberelimab (mAb } \\
\text { against PD-1) }\end{array}$ & Arcus Biosciences Inc. & Lung & NCT03846310 & $1(\mathrm{NR}, \mathrm{OL})$ \\
\hline $\mathrm{A}_{2 \mathrm{~A}} \mathrm{R} / \mathrm{A}_{2 \mathrm{~B}} \mathrm{R}$ & $\begin{array}{c}\text { Arm A: } \\
\text { AB928/Etrumadenant } \\
\text { (dual antagonist) + } \\
\text { Pegylated liposomal } \\
\text { doxorubicin (PLD) } \\
\text { Arm B: Etrumadenant + } \\
\text { nanoparticle } \\
\text { albumin-bound paclitaxel } \\
\text { (NP) } \\
\text { Arm C: Etrumadenant } \\
\text { +PLD + IPI-549 } \\
\text { (phosphoinositide-3- } \\
\text { kinase-gamma } \\
\text { inhibitor) }\end{array}$ & Arcus Biosciences Inc. & $\begin{array}{l}\text { Breast }(\mathrm{TN}) \text { or } \\
\text { gynecologic }\end{array}$ & NCT03719326 & $1(\mathrm{NR}, \mathrm{OL})$ \\
\hline $\mathrm{A}_{2 \mathrm{~A}} \mathrm{R} / \mathrm{A}_{2 \mathrm{~B}} \mathrm{R}$ & $\begin{array}{c}\text { AB928/Etrumadenant } \\
\text { (dual antagonist) }+ \\
\text { mFOLFOX }\end{array}$ & Arcus Biosciences Inc. & Gastrointestinal & NCT03720678 & $1(\mathrm{NR}, \mathrm{OL})$ \\
\hline $\mathrm{A}_{2 \mathrm{~B}} \mathrm{R}$ & PBF-1129 & Palobiofarma SL & NSCLC & NCT03274479 & $1(\mathrm{NR}, \mathrm{OL})$ \\
\hline $\mathrm{A}_{2 \mathrm{~A}} \mathrm{R}$ & $\begin{array}{c}\text { Arm 1: AZD4635 + } \\
\text { Durvalumab (mAb } \\
\text { against PD-L1) } \\
\text { Arm 2: AZD4635 + } \\
\text { Oleclumab (mAb against } \\
\text { CD73) } \\
\text { Arm 3: AZD4635 + } \\
\text { Durvalumab + Oleclumab }\end{array}$ & AstraZeneca & Prostate & NCT04089553 & 1, 2 (NR, OL) \\
\hline $\mathrm{A}_{2 \mathrm{~B}} \mathrm{R}$ & TT-4 & Tarus Therapeutics & $\begin{array}{l}\text { Gastrointestinal, } \\
\text { hepatocellular, } \\
\text { prostate }\end{array}$ & NCT04976660 & $1,2(\mathrm{OL})$ \\
\hline
\end{tabular}


Table 1. Cont.

\begin{tabular}{cccccc}
\hline Target * & $\begin{array}{c}+/- \text { Combination } \\
\text { Therapy }\end{array}$ & Company /Institution & Cancer Type & $\begin{array}{c}\text { Clinicaltrials.Gov } \\
\text { Identifier }\end{array}$ & Study Phase \\
\hline $\mathrm{A}_{2 \mathrm{~B}} \mathrm{R}$ & $\mathrm{TT}-4$ & Tarus Therapeutics & $\begin{array}{c}\text { Gastrointestinal, } \\
\text { hepatocellular, } \\
\text { prostate }\end{array}$ & NCT04976660 & $1,2(\mathrm{OL})$ \\
\hline $\mathrm{A}_{2 \mathrm{~B}} \mathrm{R}$ & $\mathrm{TT}-4$ & Tarus Therapeutics & $\begin{array}{c}\text { Gastrointestinal, } \\
\text { hepatocellular, } \\
\text { prostate }\end{array}$ & NCT04976660 & $1,2(\mathrm{OL})$ \\
\hline
\end{tabular}

* Only the target related to AR type is indicated. Abbreviations: AST: Advanced solid tumors; mAb or mab: monoclonal antibody; DB: Double blind; NA: Not applicable (safety assessment in healthy individuals); MC: multicenter; NHL: Non-Hodgkin lymphoma; NSCLC: Non-Small Cell Lung Cancer; NR: non-randomized; PC: Placebo-controlled; R: randomized; OL: Open label; TN: triple negative.

\section{Adenosine and Adenosine Deaminase in the Cells of the Immune System}

Adenosine is a key regulatory molecule in the immune system. Adenosine deaminase 1 (ADA1), the enzyme that converts adenosine into inosine, is fundamental for the development of the immune system. In fact, the congenital defect of adenosine deaminase 1 leads to severe combined immunodeficiency (SCID) with lack of $\mathrm{T}$ and $\mathrm{B}$ cells in the blood of patients. A specific toxicity for lymphoid organs due to accumulation of deoxy ATP was first assumed as responsible of such rare and severe disease. Although gene therapy was attempted, a better option for SCID patients was the replacement therapy using preparations of ADA1 conjugated to polyethylene glycol [34-45]. The optimal treatment, however, is the transplantation of bone marrow from a close relative with very similar composition of HLA human leukocyte antigens [46].

Relevant to the present discussion is the fact that the enzyme, when present in the extracellular or pericellular space, exerts multiple actions. On the one hand, it degrades extracellular adenosine, thus adjusting the level of the natural ARs agonist, whose affinity depends on the subtype. For instance, whereas the $A d o / A_{1} R$ binding is considered of high affinity, the $A_{2 B} R$ displays a very low affinity for Ado. Although poorly studied within the immune regulation context, inosine is considered a low-affinity regulatory molecule that acts on $\mathrm{A}_{3}$ Rs $[1,47]$. ADA1 may also act as a costimulatory molecule. This enzyme-independent role is relevant, among others, for lymphocyte differentiation, antigen presentation and lymphocyte activation. We found that ADA1 acts as a bridge between antigen-presenting cells and lymphocytes at the so-called immune synapse (Figure 1A). In this case, the "receptors" for ADA1 are CD26 (also known as dipeptidyl peptidase IV) on one of the cells and ARs on the other cell. At first, it was noticeable the identification of interaction of ADA1 with an AR, but indeed the enzyme may interact with more than one AR type. It is now known that the functionality of ARs is regulated by the enzymatic and extra-enzymatic action of ADA1, and that this is of special relevance in the immune system [48-58]. May inhibition of ADA1 be useful to combat cancer when Ado is friend? Deoxycoformycin (YK-176), a potent and irreversible inhibitor of ADA1, was proven efficacious in hairy cell leukemia as reported in 1992 by Shimoyama and colleagues [59]. Currently, there are several ongoing clinical trials to test efficacy in a variety of cancers of combined treatments that include deoxycoformycin (see https://clinicaltrials.gov/ accessed on 7 October 2021). May supplementation of ADA1 be useful to combat cancer when Ado is foe? This would be easy to test, as pegylated-ADA is already approved for human use. Remarkably, inhibitors of ADA1 may affect the interaction and achieve removal of ADA1, thus increasing local Ado levels and/or allosterically altering ligand binding to AR and AR-mediated signaling [60-62]. 
A

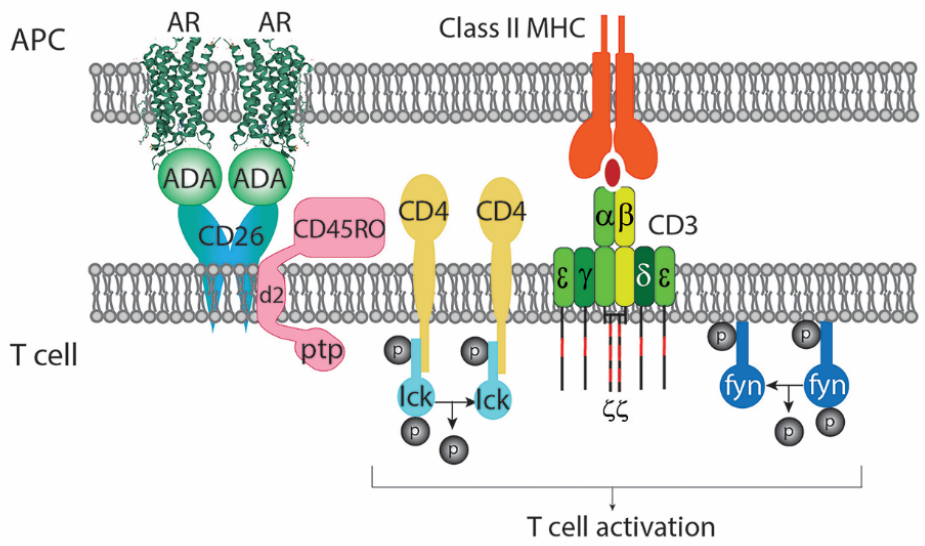

B

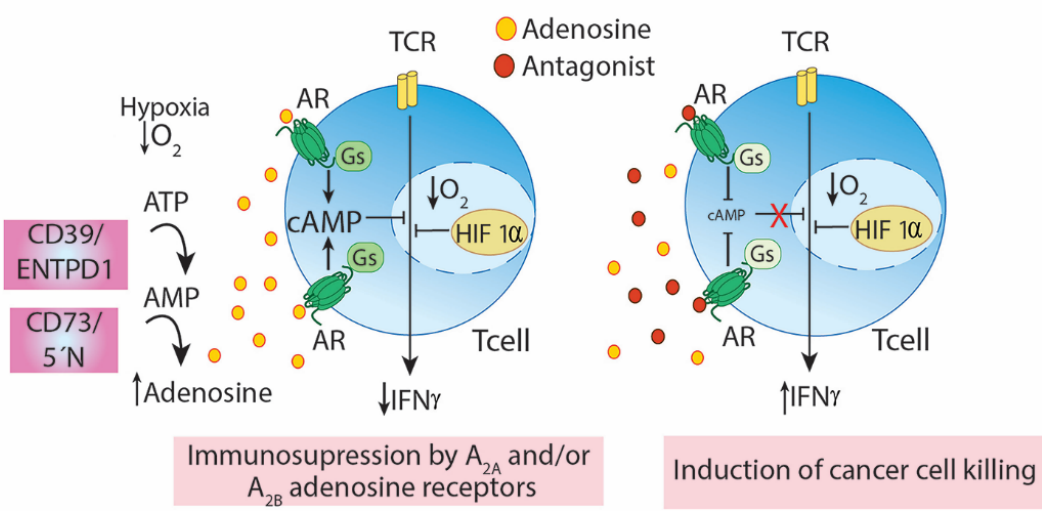

Figure 1. Immunosuppressive actions of Ado in tumor microenvironment and rescue by AR antagonists. Panel (A) Proposed model of the CD26/Ado deaminase/AR-mediated co-stimulation of T-cells upon antigen presentation. Protein Src kinases such as Lck (which constitutively binds to the cytosolic domain of T-cell coreceptors CD4 or CD8) and Fyn are activated following TCR/CD3/CD4 cross-linking on T-cell surface promoted by the interaction of Major Histocompatibility Complex (MHC) proteins with antigens in presenting cells. These Src kinases phosphorylate immunoreceptor tyrosine-based activation motif (ITAM) in the cytosolic region of $\mathrm{CD} 3 \gamma, \mathrm{CD} 3 \delta, \mathrm{CD} 3 \varepsilon$, and CD3 (red lines). Phosphorylation allows recruitment of other protein tyrosine kinases to the ITAM on CD3 , which is phosphorylated and activated by Lck. These other kinases will activate intracellular signaling pathways leading to T-cell activation. In parallel, ADA1 adenosine deaminase anchored to the $A_{2 B} A R$ on the antigen-presenting cell surface bridges the T-cell via cell surface CD26, at the same time that antigen is sensed by the T-cell receptor/CD3 complex. Subsequent to T-cell activation, CD45RO phosphatase bound to CD2, (via the $\mathrm{d} 2$ intracellular domain) is activated and recruited to the lipid rafts. The protein Tyr phosphatase (ptp) domain of CD45RO catalyzes the dephosphorylation of the regulatory domain of Src kinases including Lck and Fyn, thus inducing Src kinase activation. The model shown is similar for $\mathrm{CD} 4^{+} \mathrm{T}$ cells and $\mathrm{CD} 8^{+} \mathrm{T}$ cells. Abbreviations: $\mathrm{d} 2$, intracellular domain d2 of CD45RO; ptp, tyrosine-phosphatase domain of CD45RO. Adapted with permission from ref. [48]. 2007 Copyright Begell House Inc. Panel (B) Mechanism by which antagonists of $\mathrm{G}_{\mathrm{s}}$-coupled ARs rescue the anti-tumor activity of effector $\mathrm{T}$ cells. Elevated extracellular (Ado) in the tumor environment leads to immunosuppression. The hypoxia-induced increase in the expression of two ecto-nucleotidases, CD39 (ecto-nucleotide tri(di)phosphohydrolase-1 -ENTPD1-) and CD73 (5'-nucleotidase $\left.\left.-5^{\prime} \mathrm{N}-\right)\right)$ in the tumor microenvironment results in enhanced conversion of extracellular adenine nucleotides into extracellular Ado. Activation of ARs leads to increases in cAMP, thus leading to impaired function of the effector cells of the immune system. Hypoxia also stabilizes the transcription factor HIF-1a, which cooperates with the ARs to suppress T-cell effector functions (left). Blockade of $G_{S}$-coupled $A R s\left(A_{2 A} R\right.$ and $\left.A_{2 B} R\right)$ restores the levels of intracellular cAMP, rescues the immunosuppression and enhances cancer cell killing by effector cells (right). Adapted from ref. [63]. 


\section{5. $A_{2 A} R$ Antagonists to Boost Anti-Cancer Immunotherapy}

Adenosine and all the proteins that handle or interact with the compound, both the enzymes and the receptors, are relevant to the various sides of the immune system's action. Let us focus on AR potential as targets to improve the efficacy of anti-cancer immunotherapy. ARs are expressed in every cell of the immune system. However, the receptor type and the expression level vary from cell to cell, and they also vary according to the cell status, for instance, resting versus activated. For a detailed and relatively recent review of the expression of ARs in different immune cells see Vigano et al., 2019 [64].

The work in Michail Sitkovsky's lab has complemented previous research that shows that the $A_{2 A} R$ mediates many of the functions of Ado in the immune system [63,65-71]. Other laboratories have confirmed the findings using novel AR antagonists [72]. The investigation has been intense and prolonged in time but the conclusions can be presented succinctly. The tumor microenvironment has a high concentration of Ado that inhibits the activation of lymphocytes that are capable of killing tumor cells (Figure 1B). The mechanism is based on the increase in cAMP after the activation of $\mathrm{G}_{\mathrm{s}}$-coupled $\mathrm{A}_{2 \mathrm{~A}}$ Rs. Consequently, a selective $\mathrm{A}_{2 \mathrm{~A}} \mathrm{R}$ antagonist releases this brake and reduces cAMP levels which, in turn, make lymphocytes capable of effectively fighting/destroying tumor cells (Figure 1B).

There is a significant number of clinical trials testing the combination of $\mathrm{A}_{2 \mathrm{~A}}$ Rs with anti-cancer immunotherapies and, eventually, adding inhibitors of the enzyme that converts AMP to adenosine (CD73/5'-nucleotidase, see Figure $1 B)$. A phase $1 / 1 \mathrm{~b}$ study has been published examining in patients with "advanced malignancies" a selective $\mathrm{A}_{2 \mathrm{~A}} \mathrm{R}$ antagonist, NIR178 (PBF509), an antibody, PDR001, that binds to programmed death-1 (PD-1) protein to restore the anti-tumor activity of effector $\mathrm{T}$ lymphocytes and/or a humanized antibody against the 5'-nucleotidase, NZV930 (CTg Identifier: NCT03549000) [73]. A phase 2 trial was posted for the potential of combining NIR178 and PDR001 anti-PD-1 protein antibody in solid tumors and non-Hodgkin lymphoma (CT Identifier: NCT03207867). The primary outcome of this assay is the measurement, in 376 participants, of the response rate every 8 weeks, for 40 weeks. NIR178 is tested as monotherapy (see above) or in combination with as many as 3 different therapeutic agents: DFF332, an inhibitor of hypoxia-inducible factor (Hif)-2 $\alpha$, RAD001, an inhibitor of mammalian target of rapamycin (mTOR), and PDR001 anti-PD-1 protein antibody (CTg Identifier: NCT04895748).

A potential to boost anti-cancer immunotherapy has been attributed to antagonists of the $A_{2 B} R$, although with much less preclinical information than that available for $A_{2 A} R$ antagonists. The underlying mechanism is likely similar since $A_{2 B} R$ is coupled to $G_{s}$ and, therefore, its activation by Ado leads to increases in cAMP; accordingly, $A_{2 B} R$ antagonists can reduce cAMP levels and lead lymphocytes to restore their antitumor activities (Figure 1B). Furthermore, there is an interesting interplay between $A_{2 A}$ and $A_{2 B}$ receptors. Moriyama and Sitkovsky demonstrated that the $A_{2 A} R$ is involved in $A_{2 B} R$ expression [74] whereas, more recently, it has been shown that the functionality of $A_{2 A} R$ is affected by the expression of $\mathrm{A}_{2 \mathrm{~B}} \mathrm{R}$ and that the two proteins may interact to form novel functional units $[75,76]$. The ultimate significance of these findings is unknown, but the field has evolved to view blockade of these receptors as an effective means of fighting cancer. In fact, there are several clinical trials (in early stages) in which antagonists selective for the $A_{2 A} R$, for the $A_{2 B} R$ or dual $\left(A_{2 A} R / A_{2 B} R\right)$ are being/will be tested in patients with different cancers.

With the above-described data as background, several clinical trials to assay $\mathrm{A}_{2 \mathrm{~A}} \mathrm{R}$ and /or $A_{2 B} R$ antagonists as boosters of cancer immunotherapy have been posted. A phase 2 clinical trial, proposed for combating non-small cell lung cancer, uses etrumadenant in combination with two monoclonal antibodies: AB122 (zimberelimab, a monoclonal antibody that binds programmed death-1 protein) and AB154 (domvanalimab; a humanized monoclonal antibody directed against T-cell Ig and ITIM (TIGIT) T-cell domain) (CTg Identifier: NCT04262856). Both PD-1 and TIGIT are key mediators of the fate of tumor antigen-specific effector T cells [77,78]. A similar design (phase 1b/2) to combat "metastatic castrate resistant prostate cancer" has been posted using etrumadenant, AB122 and/or an 
inhibitor of the enzyme producing adenosine from AMP (CD73/5'-nucleotidase) (CTg Identifier: NCT04381832). One of the treatment arms of this trial will use a combination of the dual $A_{2 A} R / A_{2 B} R$ antagonist, the $A B 122$ antibody, and standard chemotherapy (enzalutamide or docetaxel). A very similar trial was posted in 2018 and was recently updated, in August 2021, for the therapy of "advanced malignancies" (CTg Identifier: NCT03629756). For prostate cancer, another selective $\mathrm{A}_{2 \mathrm{~A}} \mathrm{R}$ antagonist, AZD4635, is being used in phase 2 open-label modular study in combination with oleclumab (MEDI9447), which targets CD73/5'-nucleotidase, with durvalumab (MEDI4736), which targets PD-1 protein, or with both antibodies (CTg Identifier: NCT04089553).

For refractory of relapsed myelomas, another selective antagonist of the receptor, ciforadenant, is being tested (phase 1) in combination with daratumumab, a monoclonal antibody targeting an activator marker of lymphoid cells, CD38, with multiple enzyme activities that involve adenine nucleotides (CTg Identifier: NCT04280328). The same antagonist is planned to be tested in combination with atezolizumab (Tecentriq ${ }^{\circledR}$ ), a monoclonal antibody that binds to PD-1, in "advanced" cancers (CT Identifier: NCT02655822, phase $1 / 1 b)$.

\section{AR Ligands in Chemotherapeutic Approaches}

There are clinical trials to evaluate the efficacy of using AR ligands to enhance cancer therapies. Hopes for the efficacy of adenosine receptor ligands in cancer therapy are greatly increased when chemotherapy enhancers are considered. Although the ligands of the four ARs may be candidates, the two currently best positioned are $A_{2 A} R$ and $A_{2 B} R$ antagonists. A dual $\mathrm{A}_{2 \mathrm{~A}} / \mathrm{A}_{2 \mathrm{~B}}$ receptor antagonist is being used in several clinical trials for its potential in different malignancies. One example is the phase $1 / 1 \mathrm{~b}$ study to test the possibility of using a combination of etrumadenant and a "classical" chemotherapeutic agent, doxorubicin, in gynecological malignancies or triple negative breast cancer (CTg Identifier: NCT03719326). A more complex study for the same application uses etrumadenant in combination with chemotherapeutic agents, pegylated liposomal doxorubicin or nanoparticle albumin-bound paclitaxel and IPI-549, an inhibitor of is a phosphoinositide3-kinase-gamma (CTg Identifier: NCT03719326).

Some of the trials that use monoclonal antibodies as the main component of the anticancer immunotherapy approach are also assaying $\mathrm{A}_{2 \mathrm{~A}} \mathrm{R}$ and /or $\mathrm{A}_{2 \mathrm{~B}} \mathrm{R}$ antagonists with current chemotherapies. An example is the recently updated phase $1 / 1 \mathrm{~b}$ trial to "evaluate in participants with non-squamous non-small cell lung cancer the safety, tolerability, pharmacokinetic, pharmacodynamic, and clinical activity of etrumadenant in combination with carboplatin and pemetrexed". The trial considers to assay this combination of drugs with and without using anti-PD-1 antibodies (pembrolizumab or zimberelimab; CTg Identifier: NCT03846310).

The dual AR antagonist, etrumadenant, is being tested in phase $1 / 1 \mathrm{~b}$ trial in combination with standard chemotherapy consisting of oxaliplatin, leucovorin and 5-fluorouracil, i.e., within a standard mFOLFOX chemotherapy regimen (CTg Identifier: NCT03720678) and also with a mFOLFOX chemotherapy regimen plus zimberelimab plus/minus bevacizumab, an antiangiogenic agent monoclonal antibody (CTg Identifier: NCT04660812). The same study also contemplates an arm in which etrumadenant is combined with zimberelimab and an inhibitor of CD73/5'-nucleotidase. This multicenter randomized phase $1 \mathrm{~b} / 2$ trial aimed at treating patients with metastatic colorectal cancer is very ambitious and the results may give key information for the design of successful combination therapies.

Finally, it should be noted a phase 1 study that combines the dual $A B 928 \mathrm{AR}_{2 \mathrm{~A}} \mathrm{R} / \mathrm{A}_{2 \mathrm{~B}} \mathrm{R}$ antagonist, is in a phase $1 \mathrm{~b}$ clinical trial aimed at testing whether the combination with anti-PD1 (AB122) zimberlimab, a chemotherapeutic agent, cisplatin, and radiotherapy is, in combating locally advanced head and neck cancers, more effective than radiation therapy, single-drug chemotherapy, or other combination drug therapies (CTg Identifier: NCT04892875).

As of today, it is too soon to know whether the different AR antagonists that are being tested will have significant positive effect on boosting chemotherapy beneficial effects. It is, however, likely that more trials will be posted to test, in different cancer types and 
stages, the interventions in which treatments (chemotherapeutic and/or radiotherapeutic) incorporate $\mathrm{A}_{2 \mathrm{~A}}$ or $\mathrm{A}_{2 \mathrm{~B}}$ receptor antagonists (or dual $\mathrm{A}_{2 \mathrm{~A}} / \mathrm{A}_{2 \mathrm{~B}}$ receptor antagonists).

\section{Conclusions}

Adenosine receptor antagonists, which are generally safe, have the potential to boost chemotherapeutic or immunotherapeutic anti-cancer approaches. Due to its relevance in activated immune cells, the $\mathrm{A}_{2 \mathrm{~A}} \mathrm{R}$ is the main target in the immunotherapeutic approach. The $A_{2 B} R$ seems more promising as a target in chemotherapeutic interventions (even in radiotherapy). The existence of dual compounds, i.e., molecules acting on the $A_{2 A} R$ and on the $A_{2 B} R$, has prompted their use in both immunotherapeutic and chemotherapeutic interventions. Several ongoing clinical trials will, hopefully soon, provide the bases to approve AR ligands in anti-cancer therapy.

Author Contributions: R.F. designed the review and wrote the first version with the reports made by G.N., I.R.-R. and R.R.-S. who selected research articles and reviews and looking into the information posted in ClinicalTrials.gov. I.R.-R. made Figure 1. All authors have edited the manuscript and accepted the final version. All authors have read and agreed to the published version of the manuscript.

Funding: This work was in part supported by grants \#RTI2018-094204-B-I00 and SAF2017-84117-R funded by Spanish MCIN/AEI/10.13039/501100011033 and, as appropriate, by "ERDF A way of making Europe", by the "European Union" or by the "European Union Next Generation EU/PRTR". The research group of the University of Barcelona is considered as a group of excellence (grup consolidat \#2017 SGR 1497) by the Regional Catalonian Government, which does not provide any specific funding for reagents or for payment of services or Open Access fees).

Institutional Review Board Statement: Not applicable.

Informed Consent Statement: Not applicable.

Data Availability Statement: Not applicable.

Conflicts of Interest: Authors declare no conflicts of interest. The funders had no role in the design of the study; in the collection, analyses, or interpretation of data; in the writing of the manuscript, or in the decision to publish the results.

\section{References}

1. Bar-Yehuda, S.; Barer, F.; Volfsson, L.; Fishman, P. Resistance of Muscle to Tumor Metastases: A Role for A3 Adenosine Receptor Agonists. Neoplasia 2001, 3, 125-131. [CrossRef]

2. Alexander, S.P.; Christopoulos, A.; Davenport, A.P.; Kelly, E.; Mathie, A.; Peters, J.A.; Veale, E.L.; Armstrong, J.F.; Faccenda, E.; Harding, S.D.; et al. The concise guide to pharmacology 2021/22: G protein-coupled receptors. Br. J. Pharmacol. 2021, 178, S27-S156. [CrossRef]

3. Borea, P.A.; Gessi, S.; Merighi, S.; Varani, K. Adenosine as a Multi-Signalling Guardian Angel in Human Diseases: When, Where and How Does it Exert its Protective Effects? Trends Pharmacol. Sci. 2016, 37, 419-434. [CrossRef] [PubMed]

4. Spychala, J. Tumor-promoting functions of adenosine. Pharmacol. Ther. 2000, 87, 161-173. [CrossRef]

5. Stemmer, S.M.; Manojlovic, N.S.; Marinca, M.V.; Petrov, P.; Cherciu, N.; Ganea, D.; Ciuleanu, T.E.; Pusca, I.A.; Beg, M.S.; Purcell, W.T.; et al. Namodenoson in advanced hepatocellular carcinoma and child-pugh B cirrhosis: Randomized placebocontrolled clinical trial. Cancers 2021, 13, 187. [CrossRef] [PubMed]

6. Boison, D.; Yegutkin, G.G. Adenosine Metabolism: Emerging Concepts for Cancer Therapy. Cancer Cell 2019, 36, 582-596. [CrossRef]

7. Fishman, P.; Bar-Yehuda, S.; Synowitz, M.; Powell, J.D.; Klotz, K.N.; Gessi, S.; Borea, P.A. Adenosine Receptors and Cancer. In Handbook of Experimental Pharmacology; Springer: Cham, Switzerland, 2009; pp. 399-441.

8. Merighi, S.; Battistello, E.; Giacomelli, L.; Varani, K.; Vincenzi, F.; Borea, P.A.; Gessi, S. Targeting A3 and A2A adenosine receptors in the fight against cancer. Expert Opin. Ther. Targets 2019, 23, 669-678. [CrossRef]

9. Drury, A.N.; Szent-Györgyi, A. The physiological activity of adenine compounds with especial reference to their action upon the mammalian heart. J. Physiol. 1929, 68, 213-237. [CrossRef] [PubMed]

10. Wolf, M.M.; Berne, R.M. Coronary Vasodilator Properties of Purine and Pyrimidine Derivatives. Circ. Res. 1956, 4, 343-348. [CrossRef] [PubMed]

11. Berne, R.M. The Role of Adenosine in the Regulation of Coronary Blood Flow. Circ. Res. 1980, 47, 807-813. [CrossRef]

12. Jenner, P.; Mori, A.; Hauser, R.; Morelli, M.; Fredholm, B.B.; Chen, J.F. Adenosine, adenosine A 2A antagonists, and Parkinson's disease. Parkinsonism Relat. Disord. 2009, 15, 406-413. [CrossRef] 
13. Jenner, P. An Overview of adenosine A2A receptor antagonists in Parkinson's disease. Int. Rev. Neurobiol. 2014, 119, 71-86. [CrossRef]

14. Mizuno, Y.; Kondo, T. Adenosine A2A receptor antagonist istradefylline reduces daily OFF time in Parkinson's disease. Mov. Disord. 2013, 28, 1138-1141. [CrossRef]

15. Saki, M.; Yamada, K.; Koshimura, E.; Sasaki, K.; Kanda, T. In vitro pharmacological profile of the A2A receptor antagonist istradefylline. Naunyn Schmiedeberg's Arch. Pharmacol. 2013, 386, 963-972. [CrossRef] [PubMed]

16. Kondo, T.; Mizuno, Y.; Japanese Istradefylline Study Group. A long-term study of istradefylline safety and efficacy in patients with Parkinson disease. Clin. Neuropharmacol. 2015, 38, 41-46. [CrossRef] [PubMed]

17. Cerqueira, M.D. The future of pharmacologic stress: Selective a2a adenosine receptor agonists. Am. J. Cardiol. 2004, 94, 33-40. [CrossRef] [PubMed]

18. Garnock-Jones, K.P.; Curran, M.P. Regadenoson. Am. J. Cardiovasc. Drugs 2012, 10, 65-71. [CrossRef] [PubMed]

19. Hendel, R.C.; Bateman, T.M.; Cerqueira, M.D.; Iskandrian, A.E.; Leppo, J.A.; Blackburn, B.; Mahmarian, J.J. Initial clinical experience with regadenoson, a novel selective A 2A agonist for pharmacologic stress single-photon emission computed tomography myocardial perfusion imaging. J. Am. Coll. Cardiol. 2005, 46, 2069-2075. [CrossRef]

20. Jackson, S.; Weingart, J.; Nduom, E.K.; Harfi, T.T.; George, R.T.; McAreavey, D.; Ye, X.; Anders, N.M.; Peer, C.; Figg, W.D.; et al. The effect of an adenosine A2A agonist on intra-tumoral concentrations of temozolomide in patients with recurrent glioblastoma. Fluids Barriers CNS 2018, 15, 2. [CrossRef]

21. Jackson, S.; George, R.T.; Lodge, M.A.; Piotrowski, A.; Wahl, R.L.; Gujar, S.K.; Grossman, S.A. The effect of regadenoson on the integrity of the human blood-brain barrier, a pilot study. J. Neurooncol. 2017, 132, 513-519. [CrossRef]

22. Byrne, E.M.; Johnson, J.; McRae, A.F.; Nyholt, D.R.; Medland, S.E.; Gehrman, P.R.; Heath, A.C.; Madden, P.A.F.; Montgomery, G.W.; Chenevix-Trench, G.; et al. A Genome-Wide Association Study of Caffeine-Related Sleep Disturbance: Confirmation of a Role for a Common Variant in the Adenosine Receptor. Sleep 2012, 35, 967-975. [CrossRef] [PubMed]

23. Iglesias, I.; Albasanz, J.L.; Martín, M. Effect of Caffeine Chronically Consumed During Pregnancy on Adenosine A 1 and A 2A Receptors Signaling in Both Maternal and Fetal Heart from Wistar Rats. J. Caffeine Res. 2014, 4, 115-126. [CrossRef] [PubMed]

24. Vallon, V.; Osswald, H. Adenosine Receptors and the Kidney. In Adenosine Receptors in Health and Disease; Handbook of Experimental Pharmacology; Springer: Berlin/Heidelberg, Germany, 2009; Volume 193, pp. 443-470. [CrossRef]

25. Spielman, W.S.; Arend, L.J. Adenosine receptors and signaling in the kidney. Hypertension 1991, 17, 117-130. [CrossRef]

26. Pawelczyk, T.; Grden, M.; Rzepko, R.; Sakowicz, M.; Szutowicz, A. Region-Specific Alterations of Adenosine Receptors Expression Level in Kidney of Diabetic Rat. Am. J. Pathol. 2005, 167, 315-325. [CrossRef]

27. Vitzthum, H.; Weiss, B.; Bachleitner, W.; Krämer, B.K.; Kurtz, A. Gene expression of adenosine receptors along the nephron. Kidney Int. 2004, 65, 1180-1190. [CrossRef]

28. Blanco, J.; Canela, E.I.; Sayós, J.; Mallol, J.; Lluis, C.; Franco, R. Adenine nucleotides and adenosine metabolism in pig kidney proximal tubule membranes. J. Cell. Physiol. 1993, 157, 77-83. [CrossRef]

29. Blanco, J.; Canela, E.I.; Mallol, J.; Lluís, C.; Franco, R. Characterization of adenosine receptors in brush-border membranes from pig kidney. Br. J. Pharmacol. 1992, 107, 671-678. [CrossRef]

30. Kazemi, M.H.; Raoofi Mohseni, S.; Hojjat-Farsangi, M.; Anvari, E.; Ghalamfarsa, G.; Mohammadi, H.; Jadidi-Niaragh, F. Adenosine and adenosine receptors in the immunopathogenesis and treatment of cancer. J. Cell. Physiol. 2018, 233, $2032-2057$. [CrossRef]

31. De Araújo, J.B.; Kerkhoff, V.V.; de Oliveira Maciel, S.F.V.; de Resende e Silva, D.T. Targeting the purinergic pathway in breast cancer and its therapeutic applications. Purinergic Signal. 2021, 17, 179-200. [CrossRef] [PubMed]

32. Seitz, L.; Jin, L.; Leleti, M.; Ashok, D.; Jeffrey, J.; Rieger, A.; Tiessen, R.G.; Arold, G.; Tan, J.B.L.; Powers, J.P.; et al. Safety, tolerability, and pharmacology of AB928, a novel dual adenosine receptor antagonist, in a randomized, phase 1 study in healthy volunteers. Investig. New Drugs 2019, 37, 711-721. [CrossRef] [PubMed]

33. Chiappori, A.; Williams, C.C.; Creelan, B.C.; Tanvetyanon, T.; Gray, J.E.; Haura, E.B.; Thapa, R.; Chen, D.-T.; Beg, A.A.; Boyle, T.A.; et al. Phase I/II study of the A2AR antagonist NIR178 (PBF-509), an oral immunotherapy, in patients (pts) with advanced NSCLC. J. Clin. Oncol. 2018, 36, 9089. [CrossRef]

34. Knudsen, B.B.; Dissing, J. Adenosine deaminase deficiency in a child with severe combined immunodeficiency. Clin. Genet. 1973, 4, 344-347. [CrossRef]

35. Booth, C.; Gaspar, H.B. Pegademase bovine (PEG-ADA) for the treatment of infants and children with severe combined immunodeficiency (SCID). Biologics 2009, 3, 349-358. [CrossRef]

36. Hershfield, M.S.; Kurtzberg, J.; Aiyar, V.N.; Suh, E.J.; Schiff, R. Abnormalities in S-Adenosylhomocysteine Hydrolysis, ATP Catabolism, and Lymphoid Differentiation in Adenosine Deaminase Deficiency. Ann. N. Y. Acad. Sci. 1985, 451, 78-86. [CrossRef]

37. Blaese, R.M.; Culver, K.W.; Miller, A.D.; Carter, C.S.; Fleisher, T.; Clerici, M.; Shearer, G.; Chang, L.; Chiang, Y.; Tolstoshev, P.; et al. T lymphocyte-directed gene therapy for ADA-SCID: Initial trial results after 4 years. Science 1995, 270, 475-480. [CrossRef]

38. Hirschhorn, R. Adenosine deaminase deficiency and immunodeficiencies. Fed. Proc. 1977, 36, 2166-2170.

39. Rieger, C.H.L.; Lustig, J.V.; Hirschhorn, R.; Rothberg, R.M. Reconstitution of T-cell function in severe combined immunodeficiency disease following transplantation of early embryonic liver cells. J. Pediatr. 1977, 90, 707-712. [CrossRef]

40. Polmar, S.H.; Stern, R.C.; Schwartz, A.L.; Wetzler, E.M.; Chase, P.A.; Hirschhorn, R. Enzyme Replacement Therapy for Adenosine Deaminase Deficiency and Severe Combined Immunodeficiency. N. Engl. J. Med. 1976, 295, 1337-1343. [CrossRef] 
41. Hirschhorn, R.; Beratis, N.; Rosen, F.S. Characterization of residual enzyme activity in fibroblasts from patients with adenosine deaminase deficiency and combined immunodeficiency: Evidence for a mutant enzyme. Proc. Natl. Acad. Sci. USA 1976, 73, 213-217. [CrossRef]

42. Polmar, S.H.; Wetzler, E.M.; Stern, R.C.; Hirschhorn, R. Restoration of in-vitro lymphocyte responses with exogenous adenosine deaminase in a patient with severe combined immunodeficiency. Lancet 1975, 306, 743-746. [CrossRef]

43. Hirschhorn, R. Therapy of Genetic Disorders. N. Engl. J. Med. 1987, 316, 623-624. [CrossRef]

44. Hirschhorn, K.; Hirschhorn, R.; Hirschhorn, J.N. A Conversation with Kurt and Rochelle Hirschhorn. Annu. Rev. Genom. Hum. Genet. 2017, 18, 31-44. [CrossRef] [PubMed]

45. Hershfield, M.S.; Buckley, R.H.; Greenberg, M.L.; Melton, A.L.; Schiff, R.; Hatem, C.; Kurtzberg, J.; Markert, M.L.; Kobayashi, R.H.; Kobayashi, A.L.; et al. Treatment of Adenosine Deaminase Deficiency with Polyethylene Glycol-Modified Adenosine Deaminase. N. Engl. J. Med. 1987, 316, 589-596. [CrossRef] [PubMed]

46. Grunebaum, E.; Mazzolari, E.; Porta, F.; Dallera, D.; Atkinson, A.; Reid, B.; Notarangelo, L.D.; Roifman, C.M. Bone marrow transplantation for severe combined immune deficiency. J. Am. Med. Assoc. 2006, 295, 508-518. [CrossRef] [PubMed]

47. Jin, X.; Shepherd, R.K.; Duling, B.R.; Linden, J. Inosine binds to A3 adenosine receptors and stimulates mast cell degranulation. J. Clin. Investig. 1997, 100, 2849-2857. [CrossRef] [PubMed]

48. Franco, R.; Pacheco, R.; Gatell, J.M.; Gallart, T.; Lluis, C. Enzymatic and extraenzymatic role of adenosine deaminase 1 in T-cell-dendritic cell contacts and in alterations of the immune function. Crit. Rev. Immunol. 2007, 27, 495-509. [CrossRef] [PubMed]

49. Climent, N.; Martinez-Navio, J.M.; Gil, C.; Garcia, F.; Rovira, C.; Hurtado, C.; Miralles, L.; Gatell, J.M.; Gallart, T.; Mallol, J.; et al. Adenosine deaminase enhances T-cell response elicited by dendritic cells loaded with inactivated HIV. Immunol. Cell Biol. 2009, 87, 634-639. [CrossRef]

50. Martinez-Navio, J.M.J.M.; Climent, N.; Pacheco, R.; Garcia, F.; Plana, M.; Nomdedeu, M.; Oliva, H.; Rovira, C.; Miralles, L.; Gatell, J.M.J.M.; et al. Immunological dysfunction in HIV-1-infected individuals caused by impairment of adenosine deaminaseinduced costimulation of T-cell activation. Immunology 2009, 128, 393-404. [CrossRef] [PubMed]

51. Casanova, V.; Naval-Macabuhay, I.; Massanella, M.; Rodríguez-García, M.; Blanco, J.; Gatell, J.M.; García, F.; Gallart, T.; Lluis, C.; Mallol, J.; et al. Adenosine deaminase enhances the immunogenicity of human dendritic cells from healthy and HIV-infected individuals. PLoS ONE 2012, 7, e51287. [CrossRef]

52. Naval-Macabuhay, I.; Casanova, V.; Navarro, G.; Garcia, F.; Leon, A.; Miralles, L.; Rovira, C.; Martinez-Navio, J.M.; Gallart, T.; Mallol, J.; et al. Adenosine deaminase regulates Treg expression in autologous T cell-dendritic cell cocultures from patients infected with HIV-1. J. Leukoc. Biol. 2016, 99, 349-359. [CrossRef]

53. Martinez-Navio, J.M.; Casanova, V.; Pacheco, R.; Naval-Macabuhay, I.; Climent, N.; Garcia, F.; Gatell, J.M.; Mallol, J.; Gallart, T.; Lluis, C.; et al. Adenosine deaminase potentiates the generation of effector, memory, and regulatory CD4 ${ }^{+} \mathrm{T}$ cells. J. Leukoc. Biol. 2011, 89, 127-136. [CrossRef]

54. Franco, R.; Valenzuela, A.; Lluis, C.; Blanco, J. Enzymatic and extraenzymatic role of ecto-adenosine deaminase in lymphocytes. Immunol. Rev. 1998, 161, 27-42. [CrossRef] [PubMed]

55. Martin, M.; Centelles, J.J.; Huguet, J.; Echevarne, F.; Colomer, D.; Vives-Corrons, J.L.; Franco, R. Surface expression of adenosine deaminase in mitogen-stimulated lymphocytes. Clin. Exp. Immunol. 1993, 93, 286-291. [CrossRef] [PubMed]

56. Ciruela, F.; Saura, C.; Canela, E.I.E.I.; Mallol, J.; Lluis, C.; Franco, R. Adenosine deaminase affects ligand-induced signalling by interacting with cell surface adenosine receptors. FEBS Lett. 1996, 380, 219-223. [CrossRef]

57. Pacheco, R.; Martinez-Navio, J.M.M.; Lejeune, M.; Climent, N.; Oliva, H.; Gatell, J.M.M.; Gallart, T.; Mallol, J.; Lluis, C.; Franco, R. CD26, adenosine deaminase, and adenosine receptors mediate costimulatory signals in the immunological synapse. Proc. Natl. Acad. Sci. USA 2005, 102, 9583-9588. [CrossRef]

58. Martinez-Navio, J.M.; Climent, N.; Gallart, T.; Lluis, C.; Franco, R. An old enzyme for current needs: Adenosine deaminase and a dendritic cell vaccine for HIV. Immunol. Cell Biol. 2012, 90, 594-600. [CrossRef]

59. Shimoyama, M.; Tobinai, K.; Yamaguchi, K.; Hirashima, K.; Itoh, S.; Konishi, H.; Mikuni, C.; Togawa, A.; Hotta, T.; Toyoda, N.; et al. Treatment of Hairy Cell Leukemia with Deoxycoformycin (YK-176). Jpn. J. Clin. Oncol. 1992, 22, 406-410. [CrossRef]

60. Gracia, E.; Farré, D.; Cortés, A.; Ferrer-Costa, C.; Orozco, M.; Mallol, J.; Lluís, C.; Canela, E.I.; McCormick, P.J.; Franco, R.; et al. The catalytic site structural gate of adenosine deaminase allosterically modulates ligand binding to adenosine receptors. FASEB $J$. 2013, 27, 1048-1061. [CrossRef]

61. Gracia, E.; Cortés, A.; Meana, J.J.; García-Sevilla, J.; Herhsfield, M.S.; Canel, E.I.; Mallol, J.; Lluís, C.; Franco, R.; Casadó, V. Human adenosine deaminase as an allosteric modulator of human A1 adenosine receptor: Abolishment of negative cooperativity for $\left[{ }^{3} \mathrm{H}\right](\mathrm{R})$-pia binding to the caudate nucleus. J. Neurochem. 2008, 107, 161-170. [CrossRef]

62. Franco, R.; Casadó, V.; Ciruela, F.; Saura, C.; Mallol, J.; Canela, E.I.; Lluis, C. Cell surface adenosine deaminase: Much more than an ectoenzyme. Prog. Neurobiol. 1997, 52, 283-294. [CrossRef]

63. Kjaergaard, J.; Hatfield, S.; Jones, G.; Ohta, A.; Sitkovsky, M. A 2A Adenosine Receptor Gene Deletion or Synthetic A 2A Antagonist Liberate Tumor-Reactive CD8 + T Cells from Tumor-Induced Immunosuppression. J. Immunol. 2018, 201, 782-791. [CrossRef] 
64. Vigano, S.; Alatzoglou, D.; Irving, M.; Ménétrier-Caux, C.; Caux, C.; Romero, P.; Coukos, G. Targeting Adenosine in Cancer Immunotherapy to Enhance T-Cell Function. Front. Immunol. 2019, 10, 925. [CrossRef]

65. Willingham, S.B.; Hotson, A.N.; Miller, R.A. Targeting the A2AR in cancer; early lessons from the clinic. Curr. Opin. Pharmacol. 2020, 53, 126-133. [CrossRef]

66. Fredholm, B.B.; Chern, Y.; Franco, R.; Sitkovsky, M. Aspects of the general biology of adenosine A2A signaling. Prog. Neurobiol. 2007, 83, 263-276. [CrossRef] [PubMed]

67. Sitkovsky, M.V. Lessons from the A2A adenosine receptor antagonist- enabled tumor regression and survival in patients with treatment-refractory renal cell cancer. Cancer Discov. 2020, 10, 16-19. [CrossRef]

68. Sitkovsky, M.V.; Hatfield, S.; Abbott, R.; Belikoff, B.; Lukashev, D.; Ohta, A. Hostile, Hypoxia-A2-Adenosinergic Tumor Biology as the Next Barrier to Overcome for Tumor Immunologists. Cancer Immunol. Res. 2014, 2, 598-605. [CrossRef] [PubMed]

69. Ohta, A.; Kini, R.; Ohta, A.; Subramanian, M.; Madasu, M.; Sitkovsky, M. The development and immunosuppressive functions of $\mathrm{CD} 4+\mathrm{CD} 25+$ FoxP3+ regulatory T cells are under influence of the adenosine-A2A adenosine receptor pathway. Front. Immunol. 2012, 3, 190. [CrossRef] [PubMed]

70. Hatfield, S.M.; Sitkovsky, M. A2A adenosine receptor antagonists to weaken the hypoxia-HIF-1 $\alpha$ driven immunosuppression and improve immunotherapies of cancer. Curr. Opin. Pharmacol. 2016, 29, 90-96. [CrossRef]

71. Fong, L.; Hotson, A.; Powderly, J.D.; Sznol, M.; Heist, R.S.; Choueiri, T.K.; George, S.; Hughes, B.G.M.; Hellmann, M.D.; Shepard, D.R.; et al. Adenosine 2A receptor blockade as an immunotherapy for treatment-refractory renal cell cancer. Cancer Discov. 2020, 10, 40-53. [CrossRef] [PubMed]

72. Mediavilla-Varela, M.; Castro, J.; Chiappori, A.; Noyes, D.; Hernandez, D.C.; Allard, B.; Stagg, J.; Antonia, S.J. A Novel Antagonist of the Immune Checkpoint Protein Adenosine A2a Receptor Restores Tumor-Infiltrating Lymphocyte Activity in the Context of the Tumor Microenvironment. Neoplasia 2017, 19, 530-536. [CrossRef]

73. Naing, A.; Gainor, J.F.; Gelderblom, H.; Forde, P.M.; Butler, M.O.; Lin, C.C.; Sharma, S.; Ochoa De Olza, M.; Varga, A.; Taylor, M.; et al. A first-in-human phase 1 dose escalation study of spartalizumab (PDR001), an anti-PD-1 antibody, in patients with advanced solid tumors. J. Immunother. Cancer 2020, 8, e000530. [CrossRef]

74. Moriyama, K.; Sitkovsky, M.V. Adenosine A2A receptor is involved in cell surface expression of A2B receptor. J. Biol. Chem. 2010, 285, 39271-39288. [CrossRef] [PubMed]

75. Hinz, S.; Navarro, G.; Borroto-Escuela, D.; Seibt, B.F.; Ammon, C.; de Filippo, E.; Danish, A.; Lacher, S.K.; Červinková, B.; Rafehi, M.; et al. Adenosine A2A receptor ligand recognition and signaling is blocked by A2B receptors. Oncotarget 2018, 9, 13593-13611. [CrossRef] [PubMed]

76. Gnad, T.; Navarro, G.; Lahesmaa, M.; Reverte-Salisa, L.; Copperi, F.; Cordomi, A.; Naumann, J.; Hochhäuser, A.; Haufs-Brusberg, S.; Wenzel, D.; et al. Adenosine/A2B Receptor Signaling Ameliorates the Effects of Aging and Counteracts Obesity. Cell Metab. 2020, 32, 56-70. [CrossRef] [PubMed]

77. Chauvin, J.M.; Pagliano, O.; Fourcade, J.; Sun, Z.; Wang, H.; Sander, C.; Kirkwood, J.M.; Chen, T.H.T.; Maurer, M.; Korman, A.J.; et al. TIGIT and PD-1 impair tumor antigen-specific CD8+ T cells in melanoma patients. J. Clin. Investig. 2015, 125, 2046-2058. [CrossRef] [PubMed]

78. Ge, Z.; Peppelenbosch, M.P.; Sprengers, D.; Kwekkeboom, J. TIGIT, the Next Step Towards Successful Combination Immune Checkpoint Therapy in Cancer. Front. Immunol. 2021, 12, 699895. [CrossRef] 